\title{
Sports Diplomacy and Gender: Equal Opportunities for Women in Czech Basketball
}

\author{
KATEŘINA KOČÍ, ZBYNĚK DUBSKÝ AND ILONA BURGROVÁ
}

\section{$\checkmark$ sciendo}

Politics in Central Europe (ISSN: 1801-3422)

Vol. 17, No. 3

DOI: $10.2478 /$ pce-2021-0019

\begin{abstract}
The article focuses on the role of equal opportunities and gender in the sports environment, examining their impacts on the creation and functioning of sports diplomacy. Subsequently, in the form of a case study it first concentrates on the Czech sports environment and women's representation in international and national sports federations. In the final part, it examines the basketball environment and analyses its individual structures. Women are not sufficiently represented as coaches, referees or officials. Several main challenges are mentioned: the perception of sport as a predominantly male phenomenon, the overall society setting fixed on traditional perceptions of the role of women and men in the Czech Republic, a small number of suitable female sports models, the time-consuming character of the activities, gender stereotypes at work, the absence of suitable conditions for reconciling family and work life and the low self-confidence of female candidates. The article concludes that the Czech sports environment (including basketball) is markedly masculine, and women face a number of barriers, which in practice are reflected in the Czech Republic's representation in international sport organisations and the way in which sports diplomacy is used as a foreign policy tool.
\end{abstract}

Key words: equal opportunities, sport, sports diplomacy, soft power, basketball

\section{Introduction}

The importance of the growing participation of women as leaders is stressed in many different fields of study, including corporate governance (e.g. Kanter 1977), politics (e.g. Dahlrup, 2006) diplomacy (e.g. Aggestam and Towns, 2019) and sport. In sport, the relationship between gender diversity and sport 
governance has been studied in detail in several articles and case studies. While Adriaanse (2015) studied gender diversity in sport governance globally and examined the gender ratio on boards of National Sport Organisations in 45 countries, others focused on the issue of underrepresentation of women on sport boards in a concrete country or sport movement, such as Australia (e.g. McKay 1992, 1997; Sibson 2010), Canada (Shaw - Slack 2002; Inglis 1997), Germany (Pfister - Radtke 2009), the Netherlands (e.g. Claringbould - Knoppers 2008, 2012), New Zealand (Shaw 2006; Cameron 1996), Norway (Fasting 2000; Hovden, 2010; Skirstad 2009), the UK (e.g. Shaw - Penney 2003; Shaw Hoeber 2003) and the USA (Burton et al. 2011; Schull et al. 2013). These studies unpack the question of gender diversity on boards of sport organisations and present findings on how gender relations are created in sport organisations. Some authors explain the dominance of men in sport governance by language, practices and policy within the context of the sport organisation which favour masculinities over femininities (Shaw - Slack 2002). Hence, sport remains a male-dominated sector and progress in gender equality in this area is rather slow and only a few steps have been taken to improve diversity in the structures of sports federations (Talbot 2001, Scraton - Flintoff 2013). The others point out that such a situation is associated with the phenomenon of the glass ceiling (e.g. Hovden 2010) or with the four dimensions of gender relations, i.e. production, power, emotion and symbolism (e.g. Adriaanse 2015).

The article thus situates its research within the topic of gender diversity in sport governance, but it goes beyond and relates the issue in question with sports diplomacy, a concept which has been unpacked only recently. Therefore, its relationship with gender remains relatively under-theorised, and in the strategies of states and national sports federations rather neglected. The central argument of the study is not only to support the idea of fostering women's representation in sports governance, but also to show its impact on the sports diplomacy of a state or a sports organisation. The empirical part further explores the topic in one of the countries of the CEE region, where attention to gender issues in general is deemed insufficient (EIGE 2020). Hence, the analysis on gender and sport in the Czech Republic (CR) may contribute to the researched field, where so far mainly gender-friendly countries (e.g. Australia, New Zealand, Canada, Norway or Germany) have been scrutinised.

Two goals are identified in the study. First, based on the analysis of the relationship between gender and sports diplomacy, it identifies the main challenges which are part of academic as well as non-academic discussions. It allows us later to set an approach for the evaluation of sports diplomacy and gender at the national level. Furthermore, it enables us to examine the state of gender implementation in sports diplomacy in the $\mathrm{CR}$, and especially in the basketball segment as the second goal. The research is focused on answering two questions: (1) How important is the question of solving underrepresentation for 
the implementation of gender in sports diplomacy? (2) What specific problems can be encountered in the case of basketball in the CR with regard to the active involvement of women in sports diplomacy?

The case study therefore examines representation in national and international sport organisations in the CR. It specifically focuses on the Czech basketball environment and its individual structures, as it is the national federation with the second largest number of female members among team sports in the CR (CSU Sportovní kluby). Moreover, it is the only Czech women's team sport to participate in the summer Olympic Games since 1988 (concretely in 2004, 2008 and 2012).

The structure of the study is as follows. The article introduces first the theoretical framework by applying the liberal feminist approach while discussing gender diversity in sport governance. It also relates the problem of underrepresentation of women in these sport organisations to Kanter's concept of gender dynamics (1977) and grasps the phenomenon of the glass ceiling. This is followed by unpacking the concept of sports diplomacy and its relation to gender diversity. The empirical section then evaluates underrepresentation and analyses the gender ratio of Czech representatives in national and international sports associations. Finally, with data collected from semi-structured interviews, it unpacks the level of gender diversity in the basketball environment and discusses major barriers to women in reaching top positions, such as officials, coaches and referees, which represents a potential loss for the performance of sport associations in the diplomatic arena.

\section{Gender, sport and diplomacy}

\section{Gender and sport from theoretical point of view}

As the gender roles of men and women have started to change in society, sport as a male dominated system, which constantly reconstructs hegemonic masculinity through symbolic presentation, has been the focus of gender research since the 1980s (Chinorum et al. 2014, Everhart and Pemberton 2007). Sport is about male privileges and thus serves as one of the significant places for the confirmation of masculinity (Messner 2007). The perception of the masculine nature of sport can be identified mainly in three categories. The first category includes contact team sports with a visible degree of aggression (soccer, hockey, rugby, handball); the second category contains sports based on muscles (e.g. weightlifting) and finally, the third category includes sports directly related to 'pain and blood' (e.g. boxing; martial arts) (Meier 2005).

Various theoretical backgrounds can be used when discussing gender in relation to sport. Scraton and Flintoff (2013: 96) investigate different theoretical explanations of sports feminisms, claiming that gender relations are not static 
in their nature but may change over time and that different positions can even overlap. The article, however, draws on liberal feminism as its main focus is the representation of women and their presence in sports diplomacy.

Liberalists generally call for justice among genders and consider the distribution of benefits and burdens to be unfair, partly due to societal notions of gender differences deriving from the history of patriarchal traditions and institutions (Baehr 2013). Their approach lies on the assumption that all social activity is the result of certain restrictions and coercion. In other words, they believe that 'female subordination is rooted in a set of customary and legal constraints that blocks women's entrance to and success in the so-called public world' (Tong 1997: 12). Thus, they have been concerned with visible sources of gender discrimination, such as gendered job markets and inequitable wage scales, and with getting women into positions of authority in professions, government and cultural institutions - especially through anti-discrimination legislation and affirmative action. This understanding has put pressure on institutions to establish a complex set of internal mechanisms, rules and controls ensuring equal gender opportunities.

In this regard, in the sports arena, liberalism examines the equality of access and opportunity, different socialisation practices and discrimination (Scraton and Flintoff 2013). In other words, sport, the same as politics or diplomacy ${ }^{1}$ represents an area of human activity which needs to be accessible for women. Liberal feminists focus on discriminatory practices which prevent women from having equal access to sporting opportunities, including facilities and resources (Whalen 2017, Crosset 1995 in Scranton - Flintoff 2013). Therefore, among other issues, they also unpack the question of the representation of women in decision-making positions in sport and in higher coaching and leadership posts (Knoppers 1994 in Scranton and Flintoff 2013). The primary focus is on coaches, referees or representatives in numerous local as well as national or international sports associations and federations.

The liberal approach certainly serves as a starting point to document the real distributive inequalities between men's and women's sport or to highlight the significance of role models (Scranton and Flintoff 2013). The approach remains of utmost importance, especially when we relate the topic to the formation and implementation of findings on gender dynamics, which is linked to underrepresentation challenges and to critical mass theory. Problems for women arise because they are often located in dead-end jobs at the bottom of the organisation or appear as 'tokens' at the top (Adriaanse 2015: 151).

This study examines underrepresentation repercussions with the help of Kanter's concept of gender dynamics, gender ratios and critical mass (1977/1993),

1 The issue of women's representation in top positions is currently also addressed more in politics and diplomacy, e.g. Dahlrup 2006, Aggestam - Towns 2019, Niklasson 2020. 
which points out that relative numbers of a dominant and minority group are significant for affecting behaviour in organisations. The theory proposes that when an organisational minority (e.g. women) reaches a certain threshold or critical mass, it can influence or 'tilt' the culture of the organisation. Kanter (1977) suggested that this threshold was approximately one third of the group.

Therefore, the analysis of the Czech case (which includes quantitative as well as qualitative data) intends to examine composition in sport governance by investigating gender ratios on the boards of the main Czech and especially basketball associations, as they are the peak national bodies for a particular sport and it is at this level that important decisions are made which affect hundreds of thousands of physically active men and women, and those who want to be active, from grass-roots to the elite level. In providing a service to the general population, these publicly funded organisations are expected to adhere to ethical governance principles such as board representation of all stakeholders, including women. Moreover, they also strengthen the relevant actors in the arena of sports diplomacy.

\section{Sports diplomacy in the foreign policy and its connection with gender}

Recognition of efficiency in achieving the foreign policy goals of states and the belief that a mostly positive approach to the role of sport, sportspeople and sport organisations in international relations have contributed to the growing popularity of sports diplomacy (Nauright 2013; Trunkos - Heere 2017). The importance of sports diplomacy for foreign policy is then accepted in the contemporary world (Jackson - Haigh 2008; Black - Peacock 2013; Jennings 2013; Merkel 2016; Dubský 2018; Murray 2018; Lee 2020) ${ }^{2}$. Sport is seen as a powerful means for disseminating information internationally, strengthening reputation and developing relationships (Sanders 2016). According to Murray, sport 'can transform layers and networks into positive diplomatic relationships and, more importantly, offer an alternate channel for entrenched relations to move beyond the status quo' (Murray 2012: 588) and sports diplomacy can then be considered as one of the 'soft power' tools of the state (Melissen 2005; Grix - Brannagan 2016; Abdi - Talebpour - Fullerton et al 2019). As a respective part of public diplomacy (Özsarı et al. 2018), sports diplomacy plays an important role in communication, which is focused on achieving positive ideas about a country and aims at heightening the image and attractiveness of

2 However, negative connotations regarding the connection between sport and foreign relations are also discussed (Redeker 2008; Defrance - Chamot 2008; Jackson 2013). Sport and diplomacy in this view represent two completely different cultures - sport, unlike diplomacy, does not know consensus; in a sports match, the 'winner takes all' rule applies (Defrance - Chamot 2008: 395). Sports diplomacy is thus just an 'empty voice' (Redeker 2008). 
a country (Štulajter - Barteková - Štulajter 2013; Knott - Fyall - Jones 2015; Kobierecki - Strożek 2017).

When considering gender issues, it is important that sports diplomacy in practice does not exclusively consist of organising sports competitions and sending sportspeople to participate in them, it also has other means. A specific part of sports diplomacy is communication between sports bodies/associations/ organisations at the national and international level (Allison - Tomlinson 2017). These can be considered as new actors in diplomacy who are able to significantly affect states or to make governments influence or change their policies (Kobierecki 2019); tools such as lobbying, public relations and nation branding can be used for this (Novotný 2011). A significant starting point is the fact that sports diplomacy is carried out primarily by non-state actors but is linked to the official diplomacy of the state (Rofe 2016; Rofe 2018).

Representation in international sport organisations and associations plays a specific role and sports people in this role become sports diplomats and ambassadors (cf. Goldberg 2000; Murray 2012; Rofe 2016; Rofe 2018). The representation of state citizens in international sports institutions both raises the profile of the state and can enable the promotion of state policy goals, of course especially in sports, but also in the wider political context, as sport organisations are linked to politics and are a contemporary part of international politics (Goldberg 2000; Næss 2018).

As already argued in the previous subchapter, representation in international or national sport organisations should also be studied through the perspective of gender diversity, this time, however, in the context of sports diplomacy. In this regard, two basic levels were examined. The first level concerns the self-representation of women in national and international organisations and associations. The argument for increasing the representation of women in decision-making positions in sport is then based on a mixture of democratic/ ethical and commercial principles (Adriaanse 2015). It is therefore a combination of the assumption that women represent the stakeholders that should be involved and at the same time that their inclusion increases the range of talents available for selection in leadership positions (Adriaanse - Claringbould 2014). The second level concerns the involvement of gender as an important topic and an aspect of the implementation of sports diplomacy in other (especially developing) countries. At both levels, the problem of women's underrepresentation, the consequences of this phenomenon and, at the same time, ways to remedy can be observed. The issue may also be grasped from a different perspective (as suggested by Ryan and Dickson 2018: 343) in which 'the gender leadership problem is not the underrepresentation of women, but the dominant presence of groups of men and valued forms of masculinities'.

In any way, it can be emphasised that greater gender diversity in the structures of sport organisations presents new opportunities for sports diplomacy 
in the form of spreading new values and practices or of enhancing the organisations' performance. The involvement of women in management positions can help bring in new perspectives and ideas and can also help to improve overall governance, as it was pointed out in Australian (Sibson 2010), Norwegian (Fasting 2000) or Dutch (Claringbould - Knoppers 2008) case studies. Hence, it increases the visibility and influence of a state in different areas which can strengthen the actor and its soft power. Women might also be able to offer a different style and format of leadership that could help change the organisational culture (EIGE n.d.) as well as the commercial context (Desvaux et al. 2010).

As for the international perspective of sports diplomacy, values such as social engagement and equality also have the potential to bring specific issues to the fore, especially in the context of developing programmes. Furthermore, greater involvement of women in sports diplomacy can help create new role models for young girls (European Commission 2014). Gender equity, however, is not a goal in itself. The solution to underrepresentation has implications in a broader context in two directions. On the one hand, it continuously reduces the vision of sport as a masculine phenomenon, and on the other hand, the issue of gender in sport is becoming an important topic and a playground for activities to strengthen visibility and influence. The interplay between sports diplomacy and gender thus creates additional potential for strengthening the actor (in our case, the state) and its soft power.

\section{Methodology}

When evaluating the reflection of gender issues in sports diplomacy according to the liberal approach, it seems essential to analyse and interpret underrepresentation within sports associations and organisations, especially at the international level. The advantage is to work with hard numerical data.

However, this can only determine the situation and allow comparison. Hence, it seems appropriate to combine it with analysis of the causes of the condition. In our case, it is possible to rely on a qualitative analysis and interpret strategic documents and analyse data gathered from semi-structured interviews with relevant respondents.

In the first phase, the study contains an analysis of strategic documents on gender in sports diplomacy, adopted by federations in which the CR participates as a member. The analysis is further outlined in the context of states that have already implemented gender issues in their sports diplomacy strategies.

In the second phase, the study evaluates underrepresentation and analyses the gender ratio of Czech female representatives in international sports associations or federations, based on data provided by the Czech Olympic Committee and a report prepared by Fasting (2019), issued by the Council of Europe. It puts the numbers into the European perspective and analyses them in more 
detail in the basketball environment which, according to the study of Fasting (2019), is a sport where most federations use both measures to ensure equality and gender mainstreaming strategies.

In the third phase, the qualitative part of the research, which unpacks the level of gender diversity in the basketball environment, includes eight semi-structured interviews with three male and five female respondents (four employees of the Czech Basketball Federation, three referees and one coach) providing insight into personal experiences and work-related behaviour. The interviews were conducted from January 2019 to January 2021 by Ilona Burgrová who is well acquainted with the basketball environment. Questions were designed based on theoretical expectations and existing literature. A 'comprehensive interview' approach (Kaufmann 2010) was adopted. This qualitative data collection technique is based on conducting semi-structured interviews where the researcher has the opportunity to go beyond the 'surface' proclamations of the respondent and to examine his/her deeper thoughts and attitudes.

Participants were asked to comment on the nature of their work, on the challenges they face as well as on their perception of gender equality and possible gender differences. The semi-structured interviews with female coaches, referees and officials reveal the barriers that women in the CR face while engaging in management and professional positions in sport (and concretely in basketball). These findings will be put into the context of the theoretical debate and of the practical achievements of various actors (including states and international and national sport organisations) in the field of sports diplomacy.

\section{Sports diplomacy and gender in the CR}

\section{Gender for sports diplomacy: strategies at the national and international level}

Currently, there are international organisations and several states that already include gender issues among their strategies and activities related to sports diplomacy. Among them is the International Labour Organization (ILO), which highlights the role and/or achievements of women in a particular field of work, including sport, by portraying former athletes, coaches, administrators or journalists at special exhibitions or international film festivals or by supporting organisations that have made a significant contribution to the development of women's sports in their countries (ILO 2006).

At the EU level, the European Commission (EC) expressed its commitment, in the Women's Charter (European Commission 2010) and in the Strategy for Equality between Women and Men, to address and eliminate the gender gap in decision-making (European Commission). In the EU Strategic Actions on gender Equality in Sport (2014-2020), gender issues are defined with respect 
to individual professions within the sports environment and show sport organisations the best practices (European Commission 2014). Also, the objective 2020 is set, which includes a minimum of $40 \%$ of women on executive boards and committees of national sport governing bodies and $30 \%$ in international sports, a minimum of $40 \%$ of women in the management of professional sport administrations and governmental sport bodies. The objective serves as a target for national and international plans for strategic action. Moreover, the EIGE as an institution of the European Union published a document entitled Gender in Sport which identifies the way to change the position of women in society, focusing on gender diversity in decision-making processes and gender mainstreaming (EIGE 2015).

Apart from the EU, the Council of Europe represents another institution that develops joint projects with the EU and the sports movement, including the topic of gender equality. One such project was 'ALL IN: Towards gender balance in sport' (it ended in 2019). In addition to a survey in each participating country (whose results will be discussed more in the following section of the article) this project focused on creating a guide for sport organisations on how to achieve positive changes in their structures through gender mainstreaming.

Strategic documents adopted by major sports associations and organisations are also relevant. The International Olympic Committee (IOC) considers gender equality not only as a fundamental human right, but also as one of the basic principles of the Olympic Charter (2019). The IOC stressed that gender inequality is not only a missed opportunity within sport itself, but the uniformity caused by it can act as a risk factor in decision-making (Advancing Women in Leadership Roles Forum in Europe Vilnius, 2017). Hence, the representation of men and women in leadership and decision-making positions is a necessary condition for exploring the full potential of the sports movement. The IOC also noted that there is still a lack of positive personal role models for women in sport. Indeed, women's self-confidence is one of the factors which discourages women from applying for higher positions. As part of the administration, it encourages the IOC to identify strategic mechanisms for more women on executive boards and in administration, as well as to adopt electoral procedures to guarantee the diversity of members (IOC 2018). Furthermore, the position of women in sports structures has long been debated in European and international conferences. Every four years, the International Working Group (IWG) on Women \& Sport organises a conference in which representatives from many countries and organisations discuss topics related to women in sport. Other organisations are also active, e.g. Women's Sports International, the European Women and Sport network and the International Association for Physical Education and Sport for Girls and Women. ${ }^{3}$

3 In the Women's Sports International, there is a Czech representative who was repeatedly elected its vice-president. 
Apart from these organisations, few countries also tackle the issue of gender in their strategies of sports diplomacy. Canada, Great Britain and Australia seem to be the frontrunners. On the website of Canadian Association for the Advancement of Women and Sport and Physical Activity, the association deals with areas of women's physical activity in all its forms (including mentoring programmes for coaches as well as programmes for women who want to apply for leadership positions in sports administrations or support for minorities). It also seeks to help sport organisations ensure that their environment and activities are gender balanced. The British organisation Women in Sport has been working since 1984 to ensure that women and men have equal opportunities in society. This organisation has also prepared a document to help sports associations better involve women in their activities and structures. Mentoring and female role models across all sports levels are integrated as important activities (Women in sport 2015). The same attention to women is paid in the strategy for sports diplomacy in Australia. It does not only stress the underrepresentation of women in sporting clubs and sport organisations, but it also mentions the reason why it is necessary to change the situation. From the sports diplomacy perspective, it helps to build Australia's reputation on the global stage as a gender-friendly country, it builds trust among different communities and generates links with trade and development. Importantly, it focuses on developing youth (especially young women and girls) as emerging leaders, building leadership capacity within sport and more broadly across the Indo-Pacific region (Australian Women in Sport Advisory Group 2019: 5).

Interestingly, similar attention to the representation of women in decision-making positions in sport organisations is not paid in the sports strategies of other countries which are considered frontrunners in sports diplomacy, i.e. Wales $^{4}$ or Spain. Here, gender issues and the activity of women are viewed only as part of the development goal to be achieved on the international scene, especially in connection to less developed countries and regions (e.g. Africa is explicitly mentioned). Contrary to Canada or Britain, the internal elements of participation in decision-making seem to be rather neglected.

It is not until recently that sports diplomacy has become more widely used in the Czech environment. Within this agenda, it is the National Sports Agency, the Ministry of Foreign Affairs and the Czech Olympic Committee that play key roles in the field of Czech sports diplomacy. The international agenda and global topics are mainly devoted to the section related to Agenda 2020, prepared by the International Olympic Committee. Here, the COC is committed to 'promoting the principles of the strategic plan of the International Olympic Committee for the Development of the Olympic Movement' (IOC 2018). The activity of representatives of the Czech sports environment within the International Olympic

4 Although Wales is a constituent country of Britain, it has its own sports diplomacy strategy. 
Committee has increased over the last five years. ${ }^{5}$ Overall, however, there are only two representatives in the IOC, but no Czech female representative, nor representation in the COC's secretariat. This situation does not correspond to the results of Czech athletes in an international comparison. Underrepresentation (of both sexes) at the international level can thus be considered as a fundamental weakness of our sporting diplomatic engagement.

With regard to gender diversity, specific goals which focus directly on the sports environment were defined in the Government Strategy for Gender Equality in the Czech Republic 2014 -2020 (Office of the Government 2014). This strategy not only identifies low support for women's and girls' sports activities, but also aims to achieve balanced participation of both sexes and the application of gender mainstreaming in decision-making processes ${ }^{6}$.

Furthermore, the Commission for Equal Opportunities in Sport was established within the structures of the Czech Olympic Committee as an advisory body for equal opportunities of women and men in sport. Unfortunately, despite all the activities, the commission has neither the staff nor the financial capacity to help raise the issue of women in sport to a level that this question certainly deserves (respondent 9).

\section{Sports diplomacy in the CR and gender: the problem of underrepresentation}

Before we unpack the situation of underrepresentation in the Czech sports environment, a closer insight into Czech society is necessary to understand the context. The first women's sports association, the Czech Ladies Club, was established in the CR as early as 1865, which was almost 20 years before similar associations began to be established in Western Europe (Fasting - Knorre 2005). However, in the aftermath of the $20^{\text {th }}$ century, women's empowerment became a necessity rather than a long-accepted change. During the communist regime, women's equality became part of political doctrine. From 1948 to 1989, both women and men had to be employed and thus to contribute to the development

5 In February 2018, the chairman of the Czech Olympic Committee, Jiří Kejval, was elected a member of the IOC. Moreover, in 2019, he was appointed head of the IOC Marketing Commission and became Chairman of the Board of IOC Television and Marketing Services, which is responsible for the development and implementation of the IOC's marketing strategy and broadcasting rights for the Olympic Games. Also, Roman Kumpošt, current vice-president of the COC, was appointed member of the IOC Communication Commission.

6 Moreover, other government action plans on gender equality and sport were later published, i.e. the Action Plan for the Balanced Representation of Women and Men in Decision-Making Positions 2016-2018 (Office of the Government 2016) and the Action Plan for the Concept of Support for Sport 2016-2025 (MSMT 2016). Both specifically mention that another problematic point in promoting a balanced proportion of women and men in decision-making in public administration and public institutions is the low activity or nonactivity of the state in certain areas of public life which concerns sports and non-profit sectors. 
of socialism. However, the distribution of household responsibilities remained unchanged, which affected the role of women in sport organisations. After the end of the communist era, the question of equal opportunities became more important, especially in relation to EU enlargement.

The issue of underrepresentation in sports diplomacy in the CR must be generally placed in the context of the position of gender in society, as Czech society seems to be rather conservative and less progressive. Although the Czech institutional setting has made steps forward in the gender equality area, the recent score of the country remains lower than the EU average (56.2 points in 2020). It places the country almost at the bottom of the echelon (EIGE 2020). Especially the share of women in decision-making bodies is very low in the political, economic/business and social sectors. These data are of great importance, as they show that women's representation on the boards of political (including diplomatic), economic and social institutions represents one of the major challenges for Czech society. It includes sporting organisations, where the share of female members of the highest decision-making bodies of national Olympic sport organisations is $7.4 \%$ (EIGE 2020). Moreover, the numbers show that in the CR, only $6.7 \%$ of the decision-making positions are held by women while $93.3 \%$ are held by men in the ten most funded sports (EIGE 2020). At the same time, the study of Fasting (2019) shows that the Czech sports federation are not active in implementing measures to improve women's participation in decision-making positions.

Looking closely at the share of women in top positions in the national sports federations of 19 European states which participated in the ALL IN project, $8 \%$ of presidents are female ( 3 in total), $9 \%$ of of vice-presidents are female ( 5 in total) and $14 \%$ of board members are female (44 in total) (Fasting 2019). Unfortunately, the results have not improved significantly from 2015, when Adriaanse (2015: 154-156) presented her findings. The situation is not different for the Czech female representatives on the international scene. Their involvement in international sports federations, such as the International Handball Federation or the International Biathlon Union, is very low. Table 1 shows that there are two male representatives who have recently become presidents of international sports federations, but there are no women. There are 9 vice-presidents, but no female vice-president. Finally, there are 3 female officials (out of 14) who are currently members of the board, concretely in the World Minigolf Sport Federation and the Union Cycliste Internationale (see in Table 1).

The situation of female coaches is similar. It is estimated that female coaches represent only 20-30\% of the total number of coaches in the EU (European Commission, 2014). According to research from 2005, only $11 \%$ of professional coaches in the CR are female and $73 \%$ of the top sportswomen are still trained by men (Fasting - Knorre, 2005). The situation has improved only recently. In 2019, $33 \%$ of female professional coaches were employed by sports federa- 
Table 1: Top positions of the international sports federations - the Czech representatives

\begin{tabular}{|c|c|c|c|}
\hline & President & Vice-president & Board \\
\hline \multicolumn{4}{|c|}{ Association of Summer Olympic International Federations } \\
\hline International Weightlifting Federation & $x$ & Petr Krol & \\
\hline Union Cycliste Internationale & $x$ & $x$ & Kateřina Nash \\
\hline International Handball Federation & $x$ & $\times$ & František Táborský \\
\hline International Judo Federation & $\times$ & $\times$ & Vladimír Bárta \\
\hline \multicolumn{4}{|c|}{ Association of International Olympic Winter Sports Federations } \\
\hline International Biathlon Union & $x$ & Jiří Hamza & $\times$ \\
\hline International Ice Hockey Federation & $x$ & $x$ & Petr Bříza \\
\hline International Ski Federation & $x$ & Roman Kumpošt & $x$ \\
\hline \multicolumn{4}{|c|}{ Alliance of Independent Recognised members of Sport } \\
\hline International Casting sport Federation & $x$ & $x$ & $\begin{array}{c}\text { Josef Doležal - } \\
\text { secretary general }\end{array}$ \\
\hline World Minigolf Sport Federation & $x$ & $x$ & $\begin{array}{l}\text { Karolína Jandová - } \\
\text { Chair Medical } \\
\text { \& Anti-doping } \\
\text { Committee }\end{array}$ \\
\hline \multicolumn{4}{|l|}{ ARSF } \\
\hline $\begin{array}{l}\text { F.I.P.J.P. (Fédération Internationale de } \\
\text { Pétenque et Jeu Provencal) }\end{array}$ & $x$ & $x$ & Karel Dohnal \\
\hline International Chess Federation & $\times$ & $\times$ & Petr Pisk \\
\hline International Floorball Federation & $\times$ & Filip Šuman & $\times$ \\
\hline World Karate Federation & $x$ & $x$ & Jiří Boček \\
\hline $\begin{array}{l}\text { Federation Internationale de } \\
\text { Motocyclisme }\end{array}$ & $\times$ & $x$ & Jan Štovíček \\
\hline $\begin{array}{l}\text { International Federation of Muaythai } \\
\text { Amateur }\end{array}$ & $x$ & $x$ & Petr Ottich \\
\hline International Orienteering Federation & $x$ & $x$ & Dušan Vystavěl \\
\hline \multicolumn{4}{|l|}{ European sports federations } \\
\hline European Athletics & $\times$ & Libor Varhaník & $\times$ \\
\hline FIBA Europe & & & Michal Konečný \\
\hline
\end{tabular}




\begin{tabular}{|l|c|c|c|}
\hline & President & Vice-president & Board \\
\hline European Karate Federation & $\times$ & Jiří Boček & $\times$ \\
\hline European Squash Federation & $\times$ & Pavel Sládeček & $\times$ \\
\hline European Softball Federation & Gabriel Waage & $\times$ & $\times$ \\
\hline Tennis Europe & Ivo Kaderka & $\times$ & $\times$ \\
\hline European Canoe Federation & $\times$ & Jaroslav Pollert & $\times$ \\
\hline European Gymnastics & $\times$ & $\times$ & Vladimír Zeman \\
\hline European Handball Federation & $\times$ & $\times$ & Liběna Šrámková \\
\hline Confederation of European Baseball & & Petr Ditrich & \\
\hline
\end{tabular}

Source: Data in the table provided by the Czech Olympic Committee, September 2020.

tions (Fasting 2019). In terms of team sports, women train $29 \%$ of female athletes, $59 \%$ of female athletes are trained by men and $12 \%$ remain without a coach. Female coaches mostly work with women and children at the regional and local level, mainly in sports with a higher participation of women (dance, figure skating, gymnastics, horseback riding, etc.) (EIGE, n.d). Female coaches, therefore, focus on the part of the population and at a level which is outside the main interest of the media and which may be perceived by society as less prestigious and lower paid.

These findings only confirm that, in most areas, Czech sports organisations fail to achieve a critical mass of women's presence, as it was presented by Kanter (1977) and later concluded in other studies (Konrad et al. 2008, Torchia et al. 2011). The consequence is the loss of potential which may be manifested by enhancing the organisation's performance, including negotiations on the international scene (enriched by new perspectives and ideas), which are the corner stones of sports diplomacy. The persistence of such a pattern relates to the central argument of the liberal feminist approach, stressing the existing barriers between men and women in the public arena (including the sports environment) and pointing to the metaphor of a glass ceiling (Connell 2006).

One of the possible explanations may be the fact that the national sports federations, apart from a few institutions (such as the COC), do not implement measures or strategies to promote gender equality (e.g. mentoring programmes as in the case of Great Britain or Australia [Sibson 2010, Shaw 2006]), even though they are introduced at the international level, be it by international organisations (the ILO, the EU, the CoE or the IOC) or by international sports federations. Recently, to improve gender equality, some European sports federations have taken active steps and measures to increase the number of women in decision-making positions within their organisation. By 2015, gender quotas for the highest authorities had been introduced by nine of the 28 European 
confederations. Unfortunately, progressive action at the supranational level does not always reach national federations and local organisations. Basketball could serve as an example of a sports environment where international and national organisations do not sometimes pursue the same level of progress in promoting gender diversity in key positions, such as officials, coaches or referees. Therefore, it is the Czech basketball environment which will serve to identify the concrete challenges and barriers to women reaching leadership roles, be it an official, professional coach or referee. Indeed, in all these capacities, underrepresentation impacts the organisation's performance, including its efficiency in diplomatic activities.

\section{Gender as an issue in the Czech Basketball Federation}

The issue of women's participation in basketball is among one of the three main priorities of the International Basketball Federation's (FIBA) strategy in the period between 2019 and 2023. Its aim is to increase gender diversity, not only in FIBA structures but also within national federations (FIBA 2019). The European Basketball Federation (FIBA Europe, which represents 50 national federations) also sets several measures. It requires having at least two women and two men in decision-making positions in its statutes (EIGE n.d.). Currently, two women have seats out of nine elected positions (FIBA. n.d.) in the FIBA Europe Executive Committee and three female representatives are members of the FIBA Europe Board (FIBA, Executive Committee, Board). FIBA also established a competition commission, Women in Basketball. In addition to this, in 2019, a female representative was for the first time elected to the position of director of a regional section of FIBA (FIBA Americas).

While the FIBA implements various tools to raise the participation of women, this is not the case of national federations. The study of Fasting (2019) confirms these findings. The survey showed that in the European states which sent the questionnaires, in the basketball environment, only $3 \%$ of presidents are female, $15 \%$ of vice-presidents and $20 \%$ of members of the board in the national basketball federations are female. Interestingly also, although it is a sport where most federations use equality measures $(27 \%)$ and gender mainstreaming strategies $(47 \%)$, the implementation of measures to increase women's participation in decision-making positions is below the average: currently $53 \%$ of basketball federations in respective countries have taken steps to increase the number of women in decision-making positions. The same percentage of federations have also introduced measures to increase the number of coaches (Fasting 2019). Therefore, an analysis of the local level is necessary to examine the current state of play and to identify the major challenges and obstacles which hinder progress and lead to the underrepresentation of women in these positions. 


\section{Officials and gender problems}

The Czech Basketball Federation (CBF) has 22680 registered members in 243 different entities (CSU, Sportovní kluby 2020). The CBF does not currently have a woman in the highest body of its organisation, which is the CBF Committee (CBF 2020). Regarding the CBF General Meeting, there were four women elected out of 14 positions (CFB, General meeting). All four posts were placed in the Mandate Commission. In other bodies of the CBF, women are represented only rarely. The only exception is the CBF Arbitration Commission, where women occupied four out of six positions (CBF, commission).

The figures show that women are underrepresented within the structures of the CBF and do not participate at all at the international level (even at the Women's Committee there is a Czech male representative (CBF 2020). An interview with a CBF employee (respondent 1 ) highlighted the fact that the CBF approaches the gender issue without significant activity. 'Gender is viewed neutrally, decisions in this area are considered as personal choices and no guidelines or manual are required. We (the organisation) cannot interfere in these matters with local associations and clubs which are independent entities and thus the CBF has neither the right nor the strength to do so' (respondent 1).

The absence of discussion was also confirmed by respondent 4 (also a former basketball player): 'women often hold the positions of economist, accountant, administrative and marketing staff. They do not appear in top managerial positions as officials. This is partly due to the time-consuming and demanding combination of personal and professional life in these positions. A significant factor, however, is also the masculine environment, which still predominates among officials, and it is very difficult for a woman to make her way through it'. Respondent 4 further stated that when she came to the federation, she perceived a great willingness to change the structure of the CBF and to define individual structures, including the sports methodological section and commissions. She was also able to identify places and topics which were considered marginal by her colleagues.

Despite the low number of women in decision-making positions in the CBF, the organisation takes a part in some FIBA projects focusing on increasing the number of women in the association. These projects include Her World Her Rules (HWHR), whose aim is to attract young girls to playing basketball, and to prevent the drop out of the girls who are already playing basketball. The programme also gives an opportunity to former or current players to serve as role models. Another FIBA project is Time Out, which is an educational programme for former and current players who would like to stay active within basketball structures on the level of management and decisive positions. The CBF directly chooses the candidates who participate in this project. Respondent 1 stated that in the current year 20/21 there are two male candidates undertaking this 
programme. One of these candidates had already been replaced by another male participant due to the lack of sufficient fluency in English. Yet, according to respondent 1 , the CBF could not find any women who would be suitable for the programme and do not have any obligations such as having young children. This statement only uncovers the real barriers for female applicants which are embedded in the institutional culture and gender stereotypes remaining in the organisation. Letting one of the former female international basketball players run the programme HWHR, as it is the case in Spain, could increase the visibility of the programme and it could also create good work experience for the player.

\section{Referees and gender problems}

A similar situation occurs in the Czech Association of Basketball Referees (CABR). In the CABR, there were 21 women and 163 men in the referee profession in 2020 (respondent 2). Despite this large disparity, according to data provided by the CABR (respondent 2), it is the highest number of women in the last six seasons. In the same year, the average age of Czech female referees was 24.4 years, which is the second lowest average age overall in the given data. These figures suggest that there may be a gradual recruitment of new young adepts for the profession. However, it can also indicate the departure of experienced senior referees. So far, there has only been one woman in the highest category. No other woman in this category has replaced her since the end of her career. Interestingly, there is also one woman who participates in the international FIBA competitions at the highest level. Yet she has not yet qualified for the highest referee category in the Czech basketball environment. The inability to officiate the hardest basketball matches within the CR may be a disadvantage for her, compared to other international referees who are able to do so in their countries. These female referees gain more valuable experience on a consistent basis. The existence of a glass ceiling and the virtual impossibility of further career advancement was also claimed by respondent 8 , and it led her to seriously question her further career in this occupation. Nevertheless, according to the information obtained from CABR staff (respondent 2): 'there is no generally applicable barrier to the advancement of women into the highest category or their inclusion in the play-offs'. Such a response confirms the neutral stance and potential unwillingness of the CABR to act in these matters. This behaviour corresponds with practices identified by Shaw (2006) or Hovden (2006) in studies on New Zealand or Norwegian sports organisations, respectively. Both authors point out that to view the organisation as homogenous and gender neutral only preserves gender suppression and reproduces the male dominance in the environment.

Furthermore, a former female referee (respondent 3) mentioned several other obstacles that women in this profession have to face. Being a woman 
in a male environment was one of them. 'Some of my male colleagues had a hard time accepting that a woman could be more successful than they were. I was then met with contempt from colleagues, coaches and players at a time when I was the only woman in the highest men's basketball league in the CR' (respondent 3). She also mentioned the long journey that the profession entails: 'Basketball referee is not a full-time professional job, the referee has to take time off from his/her job in order to travel and participate in basketball matches that are played during the week. In this respect, to combine this role with a family life is extremely difficult. It is an example of the three shifts that a woman who wants to pursue a career as a referee and a working mother must undergo' (respondent 3). According to respondent 3, the professionalisation of the occupation may be helpful. If she worked as a referee as her only job, she would be greatly relieved and could devote herself fully to it. Respondent 3 also admits that some of the barriers were personal. As a result of the environment in which she participated, she began to lose internal motivation and such uncertainty prevented her from further personal development. As Shaw (2006) suggests, such reasoning is another product of maintaining the gender-neutral position of the organisation. In the words of Adriaanse (2015: 151): 'the existing gender order was understood as a women problem, a result of women's individual choices, priorities and competences, a problem beyond the responsibility of the organisation'. On the other hand, as Hovden (2008) stresses, such an existing gender order represents socially constructed power relations that could be challenged and changed when the gender dynamic changes and the critical mass is achieved. These women would no longer be taken as tokens and symbolic representatives for their category, but as a bigger group in which they could form alliances and influence the culture of the organisation.

Finally, it should be added that the aggressive behaviour of fans, coaches and players towards referees in general has multiplied. According to respondent 7 , a man is naturally afforded more respect than a woman. Respondent 8 stated that due to the lower number of female referees, people may pay closer attention to them. Therefore, their mistakes are more visible, and this can escalate in more verbal attacks on female referees than on their male counterparts (which again confirms Kanter's theoretical suggestions of women as tokens). The results of a survey of Czech sportswomen show that $32 \%$ of them do not want to become referees due to the lack of respect (Fasting - Knorre 2005). It is also interesting that while there is a greater interest in the profession of referee among individual athletes (28\%), the number of female athletes from team sports has dropped to $19 \%$ (Fasting - Knorre 2005). To increase respect, the methodological department of the CBF, in cooperation with the CABR, decided to establish 'respect meetings', in which the referees meet with the players' representatives and coaches before the match to ensure mutual respect for both professions. 
Moreover, as part of the training, one female referee is regularly sent to official FIBA training seminars, and for seven years now one referee has been participating in a camp in Slovenian Postojna, which is intended only for women. An interview with a former female referee, respondent 3 , showed that her professional inspiration was another female referee and the fact that in the club they no longer counted on her as a player. Respondent 7 stated that she came up with the idea of becoming a referee after seeing a flier, but she was later accompanied by her teammate at the time to give each other more support. As we could see from these two cases, the support of other women, role models and some sort of mentoring might be very helpful when deciding on a career as a referee.

\section{Coaches and gender problems}

Probably the largest percentage of female athletes who remain in basketball structures after their active career try to become coaches. There is also a certain number of female athletes who, along with their careers, are also involved in coaching activities (Fasting - Knorre 2005). This demonstrates that women are interested in coaching but may face some barriers which prevent them from fully pursuing this path. It is also interesting that some of the referee respondents also stated that they had tried to coach prior to pursuing a career as a referee.

According to the statistics of the Czech sports union, there are currently 840 male basketball coaches and 291 female coaches. Yet the data do not show whether all these coaches are currently assigned to any team or not (CSU, Sportovní kluby 2020).

In the past, the first woman coaching the highest women's league in the CR (now ZBL) was Světlana Bartošová, in the 1979/80 season. Since then, only a few women have been able to break the glass ceiling and hold the position of a coach or an assistant coach for an extended period of time. Currently, there are four women holding the positions of head coaches, and two women are assistant coaches in the women's basketball league. There are no women in these positions in the men's highest league (NBL). The only woman who ever coached in the NBL was Veronika Wiednerová, in 2010/11. She was officially a head coach, but in reality, she had the role of an assistant.

Currently, the CBF directly employs two women as head coaches in their 10 girls' Sports Centres (respondent 4). Even in all the national teams, the situation is not much different. The majority of the head coaches are men. The only exception is the women's team U20, where there is a woman in the position of head coach. Moreover, there is only one female assistant coach in all national teams across the categories, and she is involved with the senior women's national team (CBF, representation). An interview with a professional coach (respondent 5) only confirmed how demanding coaching is for women who want 
to perform at the highest level and at the same time have a family. In addition to the job they do, women are in charge of the household and children, and they do not have time for sports. This is especially striking for young coaches, for whom coaching is often only a poorly financially rewarded activity or even an unpaid hobby. Respondent 5 describes the coaching profession as 'a closed male company, which is difficult to enter, and therefore it is sometimes better to find your own path'. She also sees women in the coaching profession as often far more capable and hardworking than men, but due to little support from the environment and criteria that often suit men better, they do not engage in coaching for a long time. Furthermore, respondent 6 also indicates that the position of a female coach in local clubs is often associated with duties other than just training and coaching the matches. Apart from the time demanding schedule, which also includes weekends and late hours, it was also pointed out that coaching at a higher level is also linked with difficulties in the form of possible relocation. There are not many well-paid and prestigious coaching positions in the CR. Coaches who have ambitions and would like to train in top positions must therefore be prepared to move. This is certainly just as unpleasant for men as for women and their families. However, it is much harder for a woman to persuade her partner to take such an important step when there are only a few female coaches who have succeeded.

Unfortunately, these obstacles have often had a negative effect on their family life. The advice that respondent 5 would give to others who want to become professional coaches in future is, in the current social situation: 'Not to get married and not to have a family'. The coaches who tried to combine their personal and professional life at the highest level are often referred to as careerists and encounter negative reactions from their close environment. Such an approach then discourages other female coaches from pursuing this career.

The coaching association (CABT) also does not specifically target women. Only a few female coaches act as lecturers at national coaching seminars. Recently, the association has also focused on seminars with international participation and, as respondent 6 confirmed, over the past six years only one foreign female lecturer has participated. A possible increased number of foreign female lecturers could not only help to motivate young Czech coaches to further develop in their profession but also show them that female coaches are as capable and successful as their male colleagues. Moreover, according to respondent 4, the presence of women as coaches, lecturers and members of administration (management) teams is an important motivating and inspiring factor for young females. The more often young players encounter the fact that a woman may also be in various roles in sport, the more natural it may be for them to apply for such positions if they are interested.

The role models approach thus seems to be one of the core activities in fostering women's presence in sport governance. Similar actions are, as mentioned 
above, introduced in the plans of international organisations or countries which implement gender into their sport diplomatic agenda, including Australia, New Zealand or Great Britain. 'The importance of role models for women in sports is undeniable. In fact, one could assert that it is a virtuous circle. The more women take positive, leading roles as athletes, trainers, journalists and decision-makers, the more women will see that gender inequalities can be overcome - not only in sports but in all professions' (ILO 2006). It also confirms the critical mass theory, which shows that women maintaining a minority in the organisation are highly visible and are perceived as symbolic representatives who have the opportunity to inspire other women if they are motivated and supported by the association (Hovden 2010). This is often seen by liberal feminists as a starting point which fosters women's presence and leads to changes in the organisation's culture. Only then do gender-based differences become less important and women are perceived as individuals with their own skills and perspectives (Adriaanse 2015: 152). Under such circumstances, the organisation may profit from the potential that gender diversity offers, i.e. the unique skills, knowledge and experience of women, and a different voice to debates and decision-making. All of these may contribute to enhancing the external performance of the sport organisation, its negotiations with others in the international arena or to the improvement of its image towards the public in foreign countries.

\section{Conclusion}

Gender and sport are addressed simultaneously in the academic discussion. While there are various avenues to study the interrelation between concepts of gender and sports diplomacy, this article is in line with the liberal approach, centred around the issue of representation. Representation in international sport organisations plays a specific role, not only its quantity but also its quality. The involvement of women in management positions can help bring in new perspectives and ideas, and a different style and format of leadership that could help change the organisational culture. Furthermore, greater involvement of women in sport can help create new role models for young girls.

Beyond that, sportspeople in this role become sports diplomats and ambassadors who help raise the profile of the state (and their activity is therefore an important tool of public diplomacy) and can thus enable the promotion of state policy goals in sports, or even in wider international policy. Strengthening the number of women at various levels is not an end in the context of sports diplomacy; within the organisation, overall governance can be improved. Hence, it increases the visibility and influence of a state in different areas which can strengthen the actor and its soft power. In addition, the sending state presents itself as modern, democratic, open and able to reflect trends in the international community. 
In such a theoretical background, the analysis of gender and sports diplomacy in the CR confirmed several interesting findings. The issue of underrepresentation in sports diplomacy in the CR must be generally put in the context of the struggling position of gender in society. More importantly, however, underrepresentation represents a consequence of the inactivity and possible unwillingness of the Czech sports federations to tackle gender issues and implement measures within their institutions, contrary to many international sports federations. This discontinuity in actions between international and national levels seems to be the crucial problem. Progressive action at the supranational level paradoxically does not always reach national federations and local organisations. The need to increase the representation of the Czech national team is confirmed. It is, in fact, often perceived as a basic task of sports diplomacy, unfortunately, without tackling the potential of the female element for state representation and cultural change. The issue of addressing underrepresentation for the implementation of gender in sports diplomacy is considered as a goal in itself, but there is no justification for what this will allow.

Basketball could serve as an example of a sports environment where international and national organisations do not sometimes pursue the same level of progress in promoting gender diversity in key positions, such as officials, coaches or referees. The CBF defines basketball as an open, exciting, smart, common, progressive, responsible, fresh and dynamic sport. In the context of the prevailing understanding of sports diplomacy in the Czech sports environment, the $\mathrm{CBF}$ states in its materials that strategic goals are to increase the number of players, coaches, officials, referees and commissioners, and to increase the quality of federation management at all levels (CBF 2020). However, the very benefit of fulfilling these goals is completely absent, and without any connection to the gender diversity issue.

Although women's basketball is one of the most successful women's team sports in the CR, the sport is perceived predominantly as a male phenomenon. Women participating in managerial positions in this sport still face several major challenges, such as the lack of suitable female sports models, the time-consuming character of the activities, the absence of suitable conditions for reconciling family and work life or the lower self-confidence of female representatives. This is partly in line with the findings of Whalen (2017: 5), who points out that the major barriers that affect a woman's ability to make a career or to move her way up in the sports industry are networking, the absence of female role models, family and work obligations, the existence of a glass ceiling or the tendency of many women to have lower ambitions than men, and women's decisions to leave higher positions voluntarily. It also complements the analyses from other countries, such as the Netherlands or Germany, where similar challenges were identified in the past (Pfister and Radtke 2009; Claringbould - Knoppers 2008, 2012). Awareness of the potential benefits of ad- 
dressing gender imbalances for sports diplomacy is completely overshadowed by these issues. At the same time, these obstacles are so fundamental that without them, the active involvement of women in sports diplomacy cannot be considered at all. It is only after some of these barriers are acknowledged and possibly removed by the national sports federations that these federations may make better connections with their international counterparts and thus fully unfold their potential as actors in sports diplomacy.

\section{References}

Abdi, Kambiz - Talebpour, Mahdi - Fullerton, Jami et al. (2019): Identifying Sports Diplomacy Resources as Soft Power Tools. Place Branding and Public Diplomacy 15 (3): 147-155. https:// doi.org/10.1057/s41254-019-00115-9.

Adriaanse, Johanna (2015): Gender Diversity in the Governance of Sport Associations: The Sydney Scoreboard Global Index of Participation. Journal of Business Ethics 137 (1): 149-160.

Adriaanse, Johanna - Claringbould, Inge (2014): Gender equality in sport leadership; From the Brighton Declaration to the Sydney Scoreboard, International Review for the Sociology of Sport 51(5): 547-566.

Advancing Women in Leadership Roles Forum in Europe (2017): Vilnius. Vilnius commitment to change. Lithuania, Vilnius $9-11$ October 2017.

Aggestam, Karin - Towns, Ann (2019): The gender turn in diplomacy: a new research agenda. International Feminist Journal of Politics 21 (1): 9-28. DOI: 10.1080/14616742.2018.1483206.

ALL IN: Towards gender balance in sport (2019): European Union (EU) and Council of Europe (COE) joint programme: available at: https://pjp-eu.coe.int/en/web/gender-equality-in-sport/home Allison, Lincoln - Tomlinson, Alan (2017): Understanding International Sport Organisations. Principles, Power and Possibilities, Routledge.

Australian Women in Sport Advisory Group (2019): A level playing field: the case for investing in women's sport, Australian Women in Sport Advisory Group: available at: https://www.vu.edu. au/sites/default/files/level-playing-field-women-sport.pdf.

Baehr, Amy R. (2013): Liberal Feminism. In The Stanford Encyclopedia of Philosophy, edited by Edward N. Zalta. Metaphysics Research Lab, Stanford University.

Black David - Peacock, Byron (2013): Sport and Diplomacy, in Cooper, Andrew F. - Heine, Jorge Thakur, Ramesh, The Oxford Handbook of Modern Diplomacy, Oxford University Press.

Burton, Laura J. - Grappendorf, Heidi - Henderson, Angela (2011): Perceptions of gender in athletic administration: Utilizing the congruity to examine (potential) prejudice against women. Journal of Sport Management 25: 36-45.

Cameron, Jan (1996): Trailblazers: Women who manage New Zealand sport. Christchurch, New Zealand: Sports Inclined. 
CBF (2020): Česká basketbalová federace, Orgány ČBF: available at: https://www.cbf.cz/administrativa/organy-cbf.html.

Chinirum, Joy - Ogunjlmi, Lucas O. - O'Neill, Charles B. (2014): Gender and Sports in Contemporary Society. Journal of Educational and Social Research 4 (7): 25-30.

Claringbould, Inge - Knoppers, Annelies (2008): Doing and undoing gender in sport governance. Sex Roles 58: 81-92.

Claringbould, Inge - Knoppers, Annelies (2012): Paradoxical practices of gender in sport-related organisations. Journal of Sport Management 26: 404-416.

Connell, Raewyn (2006): Glass ceilings or gendered institutions? Mapping the gender regimes of public sector worksites. Public Administration Review 66: 837-849.

Crosset, Todd W. - Benedict, Jeffrey R. - McDonald, Mark A. (1995): Male student-athletes reported for sexual assault: A survey of campus police departments and judicial affairs offices. Journal of Sport \& Social Issues 19 (2): 126 - 140.

CSU, Sportovní kluby (2020): Czech Sports Union: available at: https://iscus.cz/web/sportovni-subjekty/?is_map_active=0.

Dahlrup, Drude (2006): Women, quotas and Politics. London: Routledge.

Defrance, Jacques - Chamot, Jean M. (2008): The Voice of Sport: Expressing a foreign policy through silent cultural action: The case of French foreign policy after the Second World War. Sport in Society 11(4): 395-413.

Desvaux, Georges - Devillard, Sandrine - Sancier-Sultan, Sandra (2010): Women at the top of corporations making it happen. McKinsey \& Company: available at: https://www.mckinsey.com/business-functions/organization/our-insights/women-at-the-top-of-corporations-making-it-happen

Dubský, Zbyněk (2018): Sportovní diplomacie jako součást zahraniční politiky státu. Scientia et Societas 14(1): 3-21.

EIGE (2015): Gender Equality Index 2017: Measuring gender equality in the European Union 2005-2015 - Report, European Institute for Gender Equality. ISBN 978-92-9493-768-1.

EIGE (2020): Gender Equality Index, EIGE: available at: https://eige.europa.eu/gender-equality-index/2020/domain/work/CZ.

EIGE (n.d.): Rovnost žen a mužů v oblasti sportu. Vilnius, European Institute for Gender Equality: available at: https://eige.europa.eu/sites/default/files/documents/mh0215937csn.pdf.

European Commission. Gender equality strategy, Achievements in gender equality: available at https://ec.europa.eu/info/policies/justice-and-fundamental-rights/gender-equality/gender-equality-strategy_en.

European Commission (2010): A Strengthened Commitment to Equality between Women and Men. A Women's Charter, The European Union: available at: https://eur-lex.europa.eu/LexUriServ/LexUriServ.do?uri=COM:2010:0078:FIN:EN:PDF.

European Commission (2014): Gender Equality in Sport. Proposal for Strategic Action 2014-2020. Brussels. 
Everhart, Robert B. - Pemberton, Cynthia (2007): Advancing Women in Leadership. The Institutionalization of a Gender Biased Sport Value System: available at: http://www.advancingwomen.com/awl/winter2001/everhart_pemberton.html.

Fasting, Kari (2000): Women's role in national and international sport governing bodies. In B. L. Drinkwater (Ed.), Women in sport: Volume XIII of the Encyclopaedia of Sports Medicine. An IOC Medical Committee Publication (pp. 441-451). Oxford: Blackwell Science.

Fasting, Kari - Knorre, Naděžda (2005): Ženy ve sportu v české republice: zkušenosti sportovkyň. Praha, Český olympijský výbor a Norská sportovní universita. ISBN 80-239-5723-6.

Fasting, Kari (2019): Zapojme se všichni! Směrem k genderové vyváženosti v evropském sportu. Council of Europe.

FIBA (n.d): FIBA EUROPE, Board members, FIBA: available at: https://www.fiba.basketball/europe/board

FIBA (2019): FIBA EUROPE, Women committee, FIBA: available at: https://www.fiba.basketball/ europe/committees.

Goldberg, Jeremy (2000): Sporting diplomacy: Boosting the size of the diplomatic corps, The Washington Quarterly 23 (4): 63-70.

Grix, Jonathan - Brannagan, Paul M. (2016): Of Mechanisms and Myths: Conceptualising States' 'Soft Power' Strategies through Sports Mega-Events. Diplomacy \& Statecraft 27 (2): 251-272. doi: 10.1080/09592296.2016.1169791.

Hovden, Jorid (2010): Female top leaders - prisoners of gender? The gendering of leadership discourses in Norwegian sports organizations. International Journal of Sport Policy and Politics, 2: 189-203.

Inglis, Sue (1997): Roles of the board in amateur sport organisations. Journal of Sport Management 11: 160-176.

IOC (2018): Gender Equality Review Project, IOC: available at: https://stillmed.olympic.org/media/ Document\%20Library/OlympicOrg/News/2018/03/IOC-Gender-Equality-Report-March-2018. pdf\#_ga=2.146067766.34387606.1567864358-408551781.1459505157.

ILO (2006). PLANET WORK Women in sports: How level is the playing field? available at: https:// www.ilo.org/global/publications/world-of-work-magazine/articles/WCMS_081377/lang--en/ index.htm.

Jackson, Steven J. - Haigh, Stephen (2008): Between and Beyond Politics: Sport and Foreign Policy in a Globalizing World. Sport in Society 11(4): 349-358.

Jackson, Steven J. (2013): The Contested Terrain of Sport Diplomacy in a Globalizing World. International Area Studies Review 16(3): 274-284.

Jennings, Will (2013): Governing the Games: High Politics, Risk and Mega-events. Political Studies Review 11(1): 2-14.

Kanter, Rosabeth Moss (1993): Men and Women of the Corporation. Reprint, New York: Basic Books, [1977].

Kaufmann, Jean-Claude (2010): Chápající rozhovor. Praha: Slon. 
Konrad, Alison M. - Kramer, Vicky - Erkut, Simru (2008): Critical mass: The impact of three or more women on corporate boards. Organizational Dynamics 37: 145-164.

Knoppers, Annelies (1994): Gender and the coaching profession, in Birrell, Susan - Cole, Cheryl, eds., Women, Sport and Culture, Human Kinetics.

Knott, Brendon - Fyall, Alan - Jones, Ian (2015): The Nation Branding Opportunities Provided by a Sport Mega-Event: South Africa and the 2010 FIFA World Cup. Journal of Destination Marketing \& Management 4(1): 46-56.

Kobierecki, Michał Marcin - Strożek Piotr (2017): Sport as a Factor of Nation Branding: A Quantitative Approach. The International Journal of the History of Sport 34(7-8): 697-712.

Kobierecki, Michał Marcin (2019): International sports organizations as diplomatic actors. The case of FIFA exerting influence on states, Środkowoeuropejskie Studia Polityczne 2: 105-116.

Lee, Jung Woo (2020): Sport diplomacy at the 2018 Winter Olympics in PyeongChang, The relations between North and South Korea, in Fan Hong - Lu Zhouxiang, eds., Routledge.

McKay, Jim (1992): No Pain, No Gain? Sport and Australian Culture, Prentice Hall.

McKay, Jim (1997): Managing gender: Affirmative action and organisational power in Australian, Canadian and New Zealand sport. Albany, NY: State University of New York Press.

Meier, Marianne (2005): Gender Equity, Sport and Development. Working paper. Swiss Academy for Development: available at: https:/www.sportanddev.org/sites/default/files/downloads/59__gender_equity_sport_and_development.pdf.

Melissen, Jan (2005): The New Public Diplomacy: Soft Power in International Relations, Palgrave Macmillan.

Merkel, Udo (2016): Sport as a Foreign Policy and Diplomatic Tool, in Bairner, Alan - Kelly, John Jung, Woo Lee, eds., Routledge Handbook of Sport and Politics, Routledge.

Messner, Michael (2007): Out of Play. Critical Essays on Gender and Sport, State University of New York Press.

MSMT (2016): Sport Concept for 2016 - 2025. Ministry of Education, youth and sport: available at: http://www.msmt.cz/sport-1/koncepce-podpory-sportu-2016-2025

Murray, Stuart (2012): The Two Halves of Sports-Diplomacy. Diplomacy \& Statecraft 23(3): 576-592.

Murray, Stuart (2018): Sports Diplomacy Origins, Theory and Practice, Routledge.

Næss, Hans Erik (2018): The neutrality myth: why international sporting associations and politics cannot be separated. Journal of the Philosophy of Sport 45(2): 144-160. DOI: 10.1080/00948705.2018.1479190.

Nauright, John (2013): Selling nations to the world through sports: mega-events and nation branding as global diplomacy, Public Diplomacy Magazine 9: 22-27.

Niklasson, Birgitta (2020): The Gendered Networking of Diplomats. The Hague Journal of Diplomacy 1 (aop): 1-30.

Novotný, Lukáš (2011): Trendy vývoje veřejné diplomacie v dnešní zahraniční politice. Politologický časopis /Czech Journal of Political Science 1: 65-79. 
Office of the Government (2014) Government Strategy for Equality of Women and Men in the Czech Republic for 2014 - 2020, Department of Human Rights and Minorities, The Office of the Government: available at: https://www.vlada.cz/assets/ppov/rovne-prilezitosti-zen-amuzu/Projekt_Optimalizace/Government_Strategy_for-Gender_Equality_2014_2020.pdf.

Office of the Government (2016) The Action Plan for the Balanced Representation of Women and Men in Decision-Making Positions 2016-2018. The Office of the Government of the Czech Republic: available at: https://www.vlada.cz/assets/ppov/rovne-prilezitosti-zen-a-muzu/dokumenty/Action_plan_for_Equal_Representation_Decision_Making_Positions.pdf

Olympic Charter (2019) available at https://www.olympic.cz/upload/files/Olympijska-charta-2019. pdf.

Özsarı, Arif - Fişekçioğlu, Bülent - Çetin Çağrı - Temel, Sencer (2018): Sport Diplomacy as Public Diplomacy Element. International Journal of Sport Culture and Science 6(3): 339-349.

Pfister, Gertrud - Radtke, Sabine (2009): Sport, women and leadership: Results of a project on executives in German sports organisations. European Journal of Sport Science 9: 229-243.

Redeker, Robert (2008): Sport as an Opiate of International Relations: The Myth and Illusion of Sport as a Tool of Foreign Diplomacy, Sport in Society 11(4): 494-500.

Rofe, Simon J. (2016): Sport and diplomacy: a global diplomacy framework. Diplomacy \& Statecraft 27: $212-230$.

Rofe, Simon J. (2018): Sport and Diplomacy: Games within Games, Manchester University Press.

Ryan, Irene - Dickson, Geoff (2018): The invisible norm: an exploration of the intersections of sport, gender and leadership. Leadership 14 (3): 329-346.

Sanders, Ben (2016): An own goal in Sport for Development: time to change the playing field. Journal of Sport for Development 4(6): 1-5.

Shaw, Sally (2006): Gender suppression in New Zealand regional sports trusts. Women in Management Review 21: 554-566.

Schull, Vicky - Shaw, Sally - Kihl, Lisa A. (2013): If a woman came in...she would have been eaten up alive: Analyzing gendered political processes in the search for an athletic director. Gender and Society 27: 56-81.

Shaw, Sally - Hoeber, Larena (2003): "A strong man is direct and a direct woman is a bitch": Gendered discourses and their influence on employment roles in sport organisations. Journal of Sport Management 17: 347-375.

Shaw, Sally - Penney, Dawn (2003): Gender equity policies in national governing bodies: An oxymoron or a vehicle for change? European Sport Management Quarterly 3: 78-102.

Shaw, Sally - Slack, Trevor (2002): 'It's been like that for donkey's years': The construction of gender relations and the cultures of sports organisations. Culture, Sport, Society 5: 86-106.

Sibson, Ruth (2010): "I was banging my head against a brick wall": Exclusionary power and the gendering of sport organisations. Journal of Sport Management 24: 379-399.

Scraton Sheila - Anne Flintoff (2013): Gender, Feminist Theory and Sport in Andrews, David L. Carrington, Ben. A Copanion to Sport, Blackwell Publishing. 
Skirstad, Berit (2009): Gender policy and organisational change: A contextual approach. Sport Management Review 12: 202-216.

Štulajter, Ivan - Barteková, Danka - Štulajter, Matúš (2013): Športová diplomacie. Bánská Bystrica: Belianum. Vydavatel'stvo Univerzity Mateja Bela.

Talbot, Margaret (2001): The case for physical education, in: G. Doll-Tepper \& D. Scoretz (Eds) World Summit on Physical Education (Berlin, ICSSPE).

Tong, Rosemarie (1997): Feminist Thought: A Comprehensive Introduction. Reprint. London: Routledge, 1997.

Torchia, Mariateresa - Calabro, Andrea - Huse, Morten (2011): Women directors on corporate boards: From tokenism to critical mass. Journal of Business Ethics 102: 299-317.

Trunkos, Judit - Heere, Bob (2017): Sport Diplomacy: A Review of How Sports Can Be Used to Improve International Relationships in Esherick, Craig - Baker, Rrobert - Jackson, Steven J. Sam, Michael, Case studies in sport diplomacy. Morgantown, FIT Publishers.

Whalen, Kelsey (2017): Discrimination Against Women in the Sport Industry. Eastern Kentucky University. Department of Exercise and Sport Science.

Women in sport (2015): Checklist for change. Building a sustainable pipeline to gender diversity in sport leadership, Women in sport: available at : https://www.womeninsport.org/wp-content/ uploads/2015/11/FINAL_Checklist-for-change_Trophy_Women_031115.pdf?791a8d.

\section{List of interviews}

Respondent 1, Czech Basketball Federation staff, male, Prague, 2. 1. 2019; 20. 1. 2021

Respondent 2, Czech Association of Basketball Referees, staff, male, Prague 4. 1. 2019; 7. 1. 2021; 17. 1. 2021.

Respondent 3, referee, female, Karviná, 9. 8. 2019 / Prague, 28. 1. 2021.

Respondent 4, Czech Basketball Federation staff, female, Prague, 26. 8. 2019

Respondent 5, referee, female, Prague, 25. 1. 2021.

Respondent 6, Coach, female, Hradec Králové, 23. 8. 2019.

Respondent 7, Czech Basketball Federation staff, male, Prague, 6. 1. 2021.

Respondent 8, referee, Prague, 28. 1. 2021.

Respondent 9, member of the Commission for Equal Opportunities, the Czech Olympic Committee, Prague.

Kateřina Kočí is the Assistant Professor and Research Fellow, University of Economics and Business and Associate Researcher, Institute of International Relations, Prague. As researcher she focuses on EU Actorness, Common Foreign and Security Policy, CE region in the EU and gender in diplomacy. In these research areas, as a co-author, she has recently published an article on Central Europe (Journal of International Relations and Development 2021), a chapter on Gender in the Czech 
Diplomatic services (Grada 2020) and an article on personnel representation in international organizations (Acta Politologica 2021).E-mail: katerina.koci@vse.cz.

Zbyněk Dubský is the Assistant Professor and Research Fellow at the University of Economics and Business and Associate Researcher, Institute of International Relations, Prague. He focuses specifically on energy security and international relations, security relations with an emphasis on the European continent; in the field of diplomacy, it focuses specifically on sports diplomacy and preventive diplomacy. In these research areas, he has published chapters in monographs, articles and studies. He has participated in several research grants from GAČR and TAČR. E-mail: dubskyz@vse.cz.

Ilona Burgrová is External Associate to Czech Olympic Committee and the former Czech professional basketball player. She played for Czech Republic women's national basketball team and competed at the 2012 Summer Olympics. She studied the Sports Diplomacy programme organised by the Prague University of Economics and Business and the Czech Olympic Committee. Nowadays, she closely cooperates with the Czech Olympic Committee and is a member of the working group on equal opportunities in sport.E-mail:ilonaburgrova@gmail.com. 